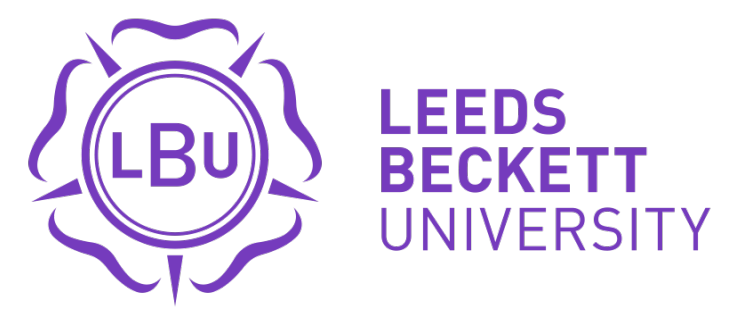

Citation:

Mitchell, J and Li, S (2016) Autonomy found: Estimating the local benefit from tourism in SIDS - the Case of Cape Verde. Journal of Policy Research in Tourism, Leisure and Events. ISSN 1940-7963 DOI: https://doi.org/10.1080/19407963.2016.1261145

Link to Leeds Beckett Repository record:

https://eprints.leedsbeckett.ac.uk/id/eprint/3386/

Document Version:

Article (Accepted Version)

This is an Accepted Manuscript of an article published by Taylor \& Francis in Journal of Policy Research in Tourism, Leisure and Events on 14 December 2016, available online: http://www.tandfonline.com/10.1080/19407963.2016.1261145

The aim of the Leeds Beckett Repository is to provide open access to our research, as required by funder policies and permitted by publishers and copyright law.

The Leeds Beckett repository holds a wide range of publications, each of which has been checked for copyright and the relevant embargo period has been applied by the Research Services team.

We operate on a standard take-down policy. If you are the author or publisher of an output and you would like it removed from the repository, please contact us and we will investigate on a case-by-case basis.

Each thesis in the repository has been cleared where necessary by the author for third party copyright. If you would like a thesis to be removed from the repository or believe there is an issue with copyright, please contact us on openaccess@leedsbeckett.ac.uk and we will investigate on a case-by-case basis. 
Please reference this paper as:

Mitchell, J. and Li, S. (2016) Autonomy found: Estimating the local benefit from tourism in SIDS - the Case of Cape Verde. Journal of Policy Research in Tourism Leisure and Events.

Autonomy found:

\title{
Estimating the local benefit from tourism in SIDS - the Case of Cape Verde
}

\author{
Jonathan Mitchell, \\ Oxford Policy Management, Oxford, UK \\ Jonathan.Mitchell@opml.co.uk
}

\begin{abstract}
ShiNa Li
International Centre for Research in Events, Tourism and Hospitality, Leeds Beckett University, UK s.li@leedsbeckett.ac.uk
\end{abstract}

\begin{abstract}
Tourism is an unusually important economic sector for the Small Island Development States (SIDS). Islands are the second most visited destinations after historic cities. The SIDS tourism is usually dependent on foreign investment and in the form of All-Inclusive (AI) system. Few studies have evaluated the economic impact of tourism on the economic development and/or poverty reduction of a SID using macro level data. And little research has used micro/firm level data to investigate the impact of tourism on the local economy of SIDS. This paper aims to evaluate the local benefits made from the development of tourism in SIDS, in particular the contribution of Al accommodation using the case of Cape Verde. It makes two main contributions: it makes the first attempt to use microeconomic data at the company level to examine the contribution of tourism in SIDS; it uses empirical data to examine the impacts of Al accommodation on the local economy. A semi-structured hotel questionnaire was applied to 13 accommodation managers and hotel owners, from small guest-houses to large 500 room All-Inclusive resorts in Sal, Boa Vista, Fogo, and Santo Antão. The results indicate that for destinations at an early stage in their development, large-scale Als may be the most effective way to achieve the growth of tourism to the point that a critical mass is achieved.
\end{abstract}

Key words: local benefits, all-inclusive, hotels, tourism in SIDS, Cape Verde 


\section{Introduction}

Although no commonly agreed definition of Small Island Developing States (SIDS) exists, they are generally characterised by being remote, small in land area and with a population of less than about one million inhabitants. They have a narrow resource base, fragile land and marine ecosystems that are susceptible to natural disasters (Lopez-Guzman et al 2013). As a result SIDS have several inherent characteristics that make broad-based economic development a challenge. Indeed, SIDS are often defined in terms of their dependency and vulnerability (Sharpley and Ussi 2012).

Tourism is an unusually important economic sector for the SIDS. Islands are the second most visited destinations after historic cities. In the most reliable source of cross-country economic statistics available - the World Bank's World Development Indicators (WDIs)- the dozen most tourism-dependent countries, measured in terms of tourism receipts as a percentage of total exports, are presented in Figure 1. For these countries, tourism generates a very large proportion of their total exports, from a 'low' of $48 \%$ in Jamaica to $82 \%$ in the Maldives (World Bank 2015). Montenegro is the only non-SIDS in this series.

\section{$<$ Insert Figure 1 around here $>$}

This data may even underrepresent the predominance of SIDS in the list of tourismdependent countries. As with any cross-country data series, not all data are available for everywhere from the WDIs. Being both small (the smallest SIDS, Niue, had a population of 1,500 in 2013) and generally low and middle-income countries - the World Development Indicators only presents tourism statistics for about half of the SIDS, so there are likely to be highly-tourism dependent SIDS that are not included in the WDI data series.

The SIDS tourism is usually dependent on foreign investment and in the form of All-Inclusive (Al) system (Barrowclough, 2007). Al is the "application of a marketing and pricing system in which all services such as breakfast, lunch, dinner, room services, local and import drinks, sport activities are covered under a fixed price package" (Ciftci, Duzakin and Onal, 2007: 269). The academic literature regarding the impact of Al resorts is fairly contested. Definitional difficulties arise from the fact that all accommodation is inclusive to some extent. Many non-Al hotels will include breakfast and/or lunch and the use of hotel facilities as part of the standard package. It widely believes that Al causes large leakages and money flows into the destination economy can be less than the part stays in the origin countries (Anderson, 2013). For example, in most Al tours, only about $20 \%$ of total tourist spending goes to the local economy (Travelwatch, 2006).

Many studies on Al are conducted from the demand side, for example the satisfaction of tourists (see Master and Prideaux, 2000; Ozdemir, Cizel and Bato, 2012) and reasons of the popularity of $\mathrm{Al}$ (see Wong and Kwong, 2004). However, the research on contribution of $\mathrm{Al}$ on the local economy is scarce. There are discussions on the limited benefits that Al resorts, 
in particular Al accommodation makes to the local economy due to leakages compared to smaller businesses, such as Bed \& Breakfast (B\&B) (see Travelwatch, 2006; Ciftci, Duzakin and Onal, 2007). These studies, however, are not rigidly conducted nor produce detailed data to reflect the impacts of $\mathrm{Al}$ on the local destination. Tourism accommodation plays an important part in the local economy in SIDS and also makes a good link with the other tourism products, such as food and beverage (Travelwatch, 2006). It is pointed out by Goodwin (2008) that empirical evidence is crucial in the studies of tourism and economic contribution.

This paper aims to evaluate the local benefits made from the development of tourism in SIDS, in particular the contribution of Al accommodation using the case of Cape Verde. It makes two main contributions. First, it uses microeconomic data at the tourist firm level to examine the contribution of tourism in SIDS, which can provide useful policy implications to tourism businesses. Second, this firm-level data is complemented with secondaryevidence to examine the impacts of tourism on the island and national economy. This blend of microand macro-economic analysis generates a more comprehensive picture, which can help to thoroughly understand the role of tourism in the economic development of SIDS.

\section{Literature review}

\section{Can tourism in the SIDS' contribute to broad-based development?}

It is no accident that many SIDS are often significant tourist destinations. The tourism industry is often the only means of creating much needed employment in such places (Shakeela et al 2011). Cross-country regressions suggest that tourism dependent countries grow faster than other countries - even taking account of the factors that normally explain growth, such as level of prosperity or investment rates and openness to trade. Smallness is generally bad for growth, but the opposite is true when the smallness of the national economy is combined with a specialization in tourism (Brau et al 2003). According to the estimation by the World Travel and Tourism Council (see Jackman, Lorde, Lowe and Alleyne, 2011), tourism in a sample of 18 SIDS significantly contributed to the total employment and GDP and in particular, the proportion of the contribution was above $50 \%$ in Anguilla, Antigua and Barbuda, Aruba and Maldives.

Tourism exists in the SIDS, often at some scale, but is this a good thing? Many think not. There is a viewpoint that tourism, through bringing large volumes of foreign exchange into an economy, can damage the non-tourist economy. This effect has been observed after oil is discovered which, like tourism, can result in a sudden inflow of hard currency into the local economy - the so-called 'Dutch disease'. The economic rationale is that, inflows of foreign exchange result in a strengthening local currency which makes exports of other goods and services uncompetitive. So a successful tourist sector may cause a decline of the agricultural 
sector (Lee, Hampton and Jeyacheya 2014). Others see the 'Dutch disease' phenomenon in more political economic terms and point to the political patronage, authoritarianism, corruption and insecure work which, not infrequently, surrounds tourist development in low-income countries.

Shakeela et al (2011) have analysed the Maldivian tourist sector to suggest that leakages undermine the benefits of tourism. Wages are low and the hiring of large numbers of expatriate labour (some $53 \%$ of the Maldivian workforce) prevents tourism from successfully reducing poverty. Beyond the tourist work-force, the economic domination of tourism by foreign-owned multinational corporations exacerbates foreign exchange 'leakages'. Many import a large proportion of their goods and services and repatriate their profits (cited in Scheyvens and Momsen 2008a)

An important concern for economists is the $f$ relatively low levels of labour productivity that characterise tourism. To illustrate this, in Cyprus and Malta, Gross Value Added per employee for hotels and restaurants was low and flat from 1999 to 2009. Unit labour costs per unit of output have grown to $63 \%$ to $80 \%$ - so employers are unable to increase wages without reducing the competitiveness of the tourist sector (Camilleri and Falzon 2013). This highlights the danger that a country which is over-reliant on tourism may successfully be able to move from Low Income to Lower Middle-Income status but then not have the potential for further transformative growth into higher levels of productivity and income (see Stephan Dercon et al 2014). This also explains the relatively high use of (cheaper) migrant labour in many advanced country tourism industries.

There are concerns about the ability of governments to translate the economic potential of tourism into an inclusive development impetus, particularly with the political priority being placed on economic development and environmental sustainability. This requires a stronger regulatory role for governments to deliver a socially-equitable outcome (Scheyvens and Momsen 2008a). In their analysis of the failure of the tourism in Zanzibar to capitalise on the opportunities of tourism to effect socio-economic development, Sharpley and Ussi (2012) highlight the impact of poor governance as a barrier to stimulating broad-based development, '...it is increasingly accepted that the nature of governance or the effectiveness of state intervention is a significant factor in the development process in developing countries in general and SIDS in particular'.

However, there are others who argue that tourism can provide a positive development impetus in SIDS. Alverez-Albelo and Hernandez-Martin (2009) have suggested that, on the basis of a theoretical model, that there will tend to be a strengthening in the terms of trade over time for a small tourist nation relative to a large, affluent source market. This is because of the higher income elasticity of demand for tourism, as a luxury good, compared with the more basic goods and services which the destination will import from the more affluent country. As a consequence, over time, the price of tourist services (sold by the small tourist nation) increases faster than the price of food and basic goods which are imported 
(into the small tourist nation) to be consumed by tourists and the host population. This suggests that integrating tourism into the development strategy of a SIDS could be a sustainable solution in the long-term.

Much of the work undertaken by the Overseas Development Institute was based upon applying an adapted value-chain analysis to 'tracing the tourism dollar' to quantify the benefits to low income groups of tourist spending in developing country destinations (Mitchell and Ashely, 2010). Obviously, the context matters and the extent to which tourist spending impacts positively on low-income groups depends upon a range of factors from the nature of the tourist product to the ability of local people to participate in touristrelated activities and the role of the state in regulating developmental outcomes. However, across a very broad range of contexts, between $10 \%-28 \%$ of tourist in-country spending accrues to low-income groups. In every case, relatively straightforward initiatives to strengthen linkages between the tourist sector and low income groups could increase the pro-poor impact of tourism in developing countries.

Several studies have evaluated the economic impact of tourism on the economic development and/or poverty reduction of a SID using macro level data. Ridderstaat, Croes and Nijkamp (2014) used an econometric methodology to investigate the relationship between tourism and long-run economic growth in Aruba. They found that not only tourism can lead to an economic development, but an economic growth can also bring further increase in tourism. Croes (2014) applied an error correction model to assess the impact of tourism on poverty reduction and the results revealed that a $1 \%$ of increase in tourism receipts would decrease 1.23 points of poverty index in Nicaragua. Pratt (2015) employed applied macro-economic modelling and found that tourism can generate economic opportunities which can benefit low-income groups but leakages are high in many SIDS. These studies have provided useful understanding to the SIDS on the role of tourism on the economic growth in SIDS. However, little research has used micro/firm level data to investigate the impact of tourism on the local economy of SIDS. This paper will fill in this gap, which will provide useful implications to the local tourism organisations in SIDS.

\section{Do All-Inclusive (AI) products have a role?}

A widely-held view in the tourism literature is that the role that Al tourism play on contributing to the local economy is limited due to large leakages generated. There are exceptions - e.g. the Sandals Al resorts in Jamaica and St Lucia owned by local business using supplies from local farmers generate large local benefits (Scheyvens and Momsen, 2008). Another view is the pragmatic one, which regards Als simply as a response to the organisational and regulatory needs of the tour operators (Cizel et al, 2011) or the demands of the tourist (Wong and Kwong, 2004). This does not, however, help us understand what are the destination impacts of Al resorts. 
There is little research on the evaluation of economic contribution of $\mathrm{Al}$ on the destination. The following reviewed studies try to identify the contribution of Al on the local economy, but there are weaknesses in the approach and limitations in findings.

Anderson (2012) examined the impact of Al on the Balearic Island through collecting visitorexit-survey questionnaires at the Airport of Mallorca in 2006. The findings show that in the Al system, the countries of origin and tourists are better off while the destination economies are not greatly benefited. Compared to the average tourism spending in 2004 in Majorca (€100.1), Al tourist spent 9.3\% less at Majorca but $9.13 \%$ more at their origin countries (Anderson, 2012). This reduced expenditure creates a challenge for the destination, particularly for tourism-specialised SIDS economies. While this study shed some light on the evaluation of the effects of Al on the local economy, the results can only tell a partial story - it shows the comparison of average spending of tourists but the overall effects of Al sector on the economy remains unknown.

Ciftci, Duzakin and Onal (2007) used three sets of questionnaires which applied to key stakeholders - tourism establishments, agencies and tourists, to capture the impacts of $\mathrm{Al}$ on the Turkish tourism sector and economy. They found that all stakeholders agreed that $\mathrm{Al}$ positively affects Turkish tourism but negatively affects the country as a whole. However, their conclusion is suggestive only. It is based only on subjective responses to only one question - "what is your opinion on the effects of the all inclusive system on the Turkish Tourism" (pp283-285). The responses to this question may, or may not, reflect the actual impacts of Al on the local economy.

Travelwatch (2006) investigated the economic benefits of tourism to the local economy through 10 interviews with tour operators and another 30 interviews with other key stakeholders from e.g. tourist boards and the hospitality sector. The results suggest that, while non-Al businesses generate a higher proportionate contribution to the local economy in terms of their total turnover and employment, Al hotels produce higher local spend in absolute value terms. For example, in different categories of spending by accommodation, $74 \%$ of the spend on rooms by Al hotels accrued to the local economy and this figure was $90 \%$ for guesthouses/B\&B and 60\% for self-catering accommodation (Travelwatch, 2012). Although the different views of key stakeholders regarding the contribution of $\mathrm{Al}$ to the local economy are reported by Travelwatch (2012), the perception that Als generate less local benefit was not supported by analytical data.

\section{Background to economic and tourism development in Cape Verde}

Cape Verde is a small archipelago of ten islands (nine inhabited) located in the Atlantic Ocean off the west coast of Africa (see Figure 2). Independence was achieved from the Portuguese in 1975 and the Government embarked on a socialist and Africanist policy 
agenda (Meyns 2002). During this period, the economy was dependent upon development aid, remittances from migrant workers and some small-scale fishing and agriculture and unsustainable, heavily-subsidised port industries. The only prospect for sustainable development and ending the departure of large numbers of migrant workers (more Cape Verdeans live in the US and Europe than Cape Verde) was to develop the indigenous economy. Economic reforms were launched by the new democratic Government from the early 1990s, aimed at developing the private sector and attracting foreign investment to diversify the economy. Cape Verde has demonstrated and, to an extent, marketed its achievements in the area of good governance and a plural democracy (Baker 2009 and). The Government have also maintained a robust non-aligned foreign policy for 25 years.

\section{$<$ Insert Figure 2 around here $>$}

The population of Cape Verde are mainly on the islands of Santiago, Sao Vicente and Santo Antao. The main 'tourist' islands of Sal and Boa Vista were almost uninhabited prior to the tourism boom in the late 1990s. Until the mid-1990s, arrivals to Cape Verde did not exceed 30,000 per year and consisted mostly of members of the diaspora community visiting family and friends. Yet during the period from 1999 to 2014, international tourism arrivals grew at a cumulative annual rate of over $14 \%$ percent (from around 67,000 to 494,0001 ). This is a very rapid growth rate that is over three times the global average during the same period (just over 4 percent). The country even experienced growth during the global economic crisis of 2008-2009 (see Figure 3).

\section{$<$ Insert Figure 3 around here $>$}

Government decided to open up the Cape Verde economy to foreign investors in the 1990s and make a number of strategic investments - particularly in air transport infrastructure, energy and designating sites for private sector tourist investment. The focus was on large resorts on Sal and Boa Vista. Tourism growth in Cape Verde has been largely driven by outsiders. A small number of European tour operators are servicing a handful of very large Al resorts on two of the islands of the Archipelago and appear to be making a reasonable return. This, in itself, is an impressive story of economic growth in a SIDS. The relevant question for us, though, is what has been the development impact of this tourism growth?

\footnotetext{
${ }^{1}$ International tourism arrival statistics in Cape Verde are disputed because the estimates from the Air Service Authority (ASA) of Cape Verde are based upon international air traffic and include visitors who are in transit and who are migrant workers (i.e. people who arrive at airports in Cape Verde but are not tourists). It is for this reason that this study uses World Bank figures which exclude transit passengers and migrants from the tourism statistics.
} 
Since the late 1990s, the size of economy has more than doubled and per capita incomes have risen $4.6 \%$ per year, reaching US\$3,270 in 2010. In a period of 15 years the Cape Verde economy made the transition from a dependency upon external transfers, uncompetitive manufacturing and unproductive primary sector activities - to the service sector, with an emphasis on tourism. The direct contribution to the national economy of the primary sector (agriculture and fishing) and industry have both reduced from around $20 \%$ of the economy to just $5 \%$ over this period. The old staples of the national economy, aid and remittances have held constant in real terms - but have reduced as a proportion of the rapidly expanding economy. Over the same period, the direct contribution of tourism has increased to some $20 \%$ of the economy. The World Travel \& Tourism Council (WTTC) estimates the tourism economy as a whole is about $40 \%$, when taking account of the impact of sectors such as air transport and the construction of tourism facilities (WTTC 2015).

\section{<Insert Figure 4 around here $>$}

In 2010, Cape Verde graduated from UN Group of Least Developed Countries to MiddleIncome Country status, only the second country ever to have made this transition (Botswana being the first). This reflected the spectacular increases in per-capita income since the late 1990s - and, as this analysis demonstrates, these were almost entirely attributable to the growth of tourism (Lopez-Guzman et al 2013).

Cape Verde has been selected as the subject of this case study because the authors have access to unusually good primary and secondary data regarding the growth of tourism and the impact this has had on development - a consequence of a series of donor-funded research projects from 2007 to 2012. Cape Verde is one of the SIDS that, one might expect, would conform to the doomsayers' stereotype. It has a small population, spread over an archipelago of 9 islands off the coast of West Africa. It entered the 1990s with a very fragile economy and a $49 \%$ poverty rate and virtually no tourist sector. However, since then, tourism has grown rapidly on the basis of almost entirely foreign-owned, very large, $\mathrm{Al}$ resorts, which many would contend is the least conducive context for broad-based development. Therefore, with a combination of robust local data and a rather specific model of tourist development followed in Cape Verde, this case study is a good opportunity to assess whether tourism growth can be a viable tool for broader socio-economic development in a SIDS context. And, if it can, what may be learned from this experience?Poverty has dropped precipitously since the Cape Verdean economy was liberalised. In 1990, Cape Verde had a poverty rate of 49 percent. In 2000 this had dropped to 37 percent and to 27 percent by 2010 (See Figure 5). By 2015, the rate of poverty was estimated to be $24.5 \%$ (United Nations 2010). This is a truly remarkable achievement for a West African SIDS. The islands with most tourist flows and the Al resorts have had the fastest percentage reduction in poverty and currently have the lowest poverty incidence in 
Cape Verde. Sal's poverty rate is 10 percent and Boa Vista's is 11 percent in 2010. Since these two islands had virtually no economic base prior to the arrival of tourism and are almost totally dependent on Als, this would suggest that the tourism sector, including the $\mathrm{Al}$ tourism development model, can successfully lift people out of poverty at scale.

What is intriguing about this data is that even islands with limited tourism flows, like St Nicolaus, Maio and Brava, have also experienced rapid reductions in poverty. This suggests that, through mechanisms such as internal labour migration and taxation, the benefits of tourism development can diffuse even to places which rarely see a tourist. Interestingly, islands with a different model of tourism in Cape Verde, like Santiago (business tourism around Praia, the Capital) and eco-tourism in Sao Antao and Fogo have experienced slower rates of poverty reduction than most of the islands with very limited tourist flows.

\section{$<$ Insert Figure 5 around here $>$}

We can further isolate tourism's impact on poverty by analyzing the 2007 household survey together with the 2010 census, which indicate poverty levels by sector of employment. The data show that households containing a person working in the tourism sector, have a low incidence of poverty. While the national poverty headcount in 2010 was $27 \%$, poverty among households dependent on the tourism sector is a much lower figure of $12 \%$. In these macro-economic statistics, we cannot differentiate between tourism workers in different types of tourist segments. However, we do know that the great majority of tourism workers in Cape Verde are linked to Al resorts. Our hotel interviews also revealed that tourist wages are significantly higher on the main tourist islands of Sal and Boa Vista, than elsewhere.

In marked contrast with households containing a tourist worker, households working in the agricultural and fisheries sectors are significantly worse-off than the national average . Agriculture has a poverty incidence of $44 \%$ and fisheries $35 \%$. This provides further compelling evidence that tourism growth, which is associated with a movement of workers out of the primary and manufacturing sectors and into the service and construction sectors, has been the primary driver of the reduction in poverty seen in Cape Verde since the 1990s.

Researchers have also carefully analysed a variable which is often overlooked, what local people think about tourism in Cape Verde (Riberio et al 2013 and Canizares et al 2014). These results of these studies reveal the strong cultural differences between different islands in Cape Verde and their contrasting experiences of national tourist activity. Notwithstanding this, the positivity of local perceptions of tourism, and its potential to benefit the development of the Archipelago, are important findings from these studies. 


\section{Methodology}

The approach of this study is developed based on authors' previous research which was undertaken in Cape Verde in 2008 for the United Nations Development Programme (see Mitchell 2008²).

A semi-structured hotel questionnaire was applied to 13 accommodation managers and hotel owners, from small guest-houses to large 500 room All-Inclusive resorts in Sal, Boa Vista, Fogo, and Santo Antão (See Table 1). To derive useful comparisons, managers across the range of accommodation types (Als and B\&Bs) across different size categories and price points were surveyed.

The questionnaire is designed based on the World Bank study of 2012. It was applied to the manager of the hotel by an experienced researcher and typically takes about two hours to complete. The format of this questionnaire has been refined over the course of some seven years and studies across a dozen different developing countries. It was designed to collect information which allows researchers to model and validate hotel revenue and costs and physically performance (i.e. occupancy, local sourcing, etc) from respondents that are often reluctant to share what is regarded as sensitive commercial information.

In order to depict a complete picture of the economic performance of the hotels, other relevant key stakeholders on the supply chain are also interviewed which include private sector operators whose activities impact on the tourist sector: suppliers, construction companies, in-bound tour operators and excursion destinations. Whilst a private sector activity, tourism is also heavily dependent upon the activities of the public sector and we interviewed civil servants, politicians, donors from a range of departments and agencies within government. The format of these semi-structured interviews has also been refined over seven years of field tests. The findings of this survey were discussed during a two day workshop with the National Cabinet of Cape Verde in April 2012.

\section{<Insert Table 1 around here>}

\section{Results and Analysis}

Accommodation in Cape Verde is heavily focused on the islands of Sal and Boa Vista, a trend which has been increasing steadily since the early 2000s. As of 2011, there were 7,901 rooms in 195 hotels spread across all nine of the inhabited islands, yet over three-quarters

\footnotetext{
${ }^{2}$ http://www.odi.org/sites/odi.org.uk/files/odi-assets/publications-opinion-files/5850.pdf - this document also contains the hotel survey instrument in the annex
} 
of these rooms were located on Sal and Boa Vista, with roughly equal numbers of rooms on each. Guest night figures from 2015 reveal that the two islands have an astounding 80 percent share of national tourist bed nights. The market share of national tourist bed nights accounted for by Sal and Boa Vista was $90 \%$ in 2011, which indicates that the process of geographic disbursal of tourism is already underway.. However, it is likely that these two islands will continue to dominate Cape Verde's hotel market for the foreseeable future.

Even within Sal and Boa Vista, tourist activity is heavily concentrated in a small number of very large Al resorts. The four largest hotels on each of these two islands have a combined total of 4,157 rooms, or 53 percent of all hotel rooms in the country. In addition, because they have high double-room occupancy ratios and high room occupancy figures overall, these Als accommodate an even larger share of the total tourist flow. We estimate that these eight hotels accommodated some 326,900 tourists in 2011, which represents around two thirds of total international tourism arrivals to Cape Verde.

Of the eight Als, three are owned by RIU Resorts. They have an average size of 901 rooms and represent about 34 percent of the national accommodations stock. This reflects the prominence of the TUI Group ${ }^{3}$, a European outbound tour operator that owns a significant stake in RIU Resorts. We estimate that the TUI Group alone is responsible for nearly half of all tourist arrivals to Cape Verde.

The analysis in Figure 7 below examines the local benefit generated by these different types of accommodation and presents the results as the scale of the local benefit per hotel room per day, represented as the area of the bubble. Local benefit is defined as the sum of local staff salaries, procurement of local Fresh Fruit and Vegetables (FFV) and fish, and taxes.

In Figure 7, the local benefit bubbles are located in a graphic which illustrates two important hotel performance statistics. The first is the Average Daily Rate (ADR), which is calculated as the average room rate per occupied room. The ADR is presented on the horizontal axis. This illustrates that many of the hotel rooms in Sal and Boa Vista have an ADR which exceeds $€ 100$ a day. In the recent past, hotel investors were concerned that the huge supply of modest quality accommodation in the RIU resorts would undermine the market for high quality accommodation on the tourist islands in Cape Verde. However, recent developments by The Resort Group (which in 2011 opened the 271 room Tortuga Melia in Sal as an up market all-inclusive resort and have two further properties under construction) and upgrading the management of other resorts has demonstrated that Cape Verde can still attract robust room rates. In Fogo and Santo Antão the graphic illustrates that ADRs are much lower, averaging about $€ 50$ per occupied room per day.

The vertical axis presents the second key hotel performance statistic, the average room revenue per available room per day (RevPAR). The RevPAR is essentially the ADR that also takes into account the level of room occupancy in the hotel. The distinction between the

\footnotetext{
${ }^{3}$ TUI North East includes the UK and Nordic source markets and TUI Central Europe is principally the German market with some of the Austrian and Polish market.
} 
ADR and RevPAR is critical to understanding tourism in Cape Verde. In the 'tourist islands' of Sal and Boa Vista, not only are room rate figures healthy but room occupancy rates are also robust.

At an average occupancy of about 70 percent, the RevPAR figure is only about one-third lower than the ADR figure for these hotels. However, outside the main tourist flows - on the islands of Fogo and Santo Antão where room occupancy rates are much lower and often below 50 percent - this generates a RevPAR figure much lower than the ADR figure. The consequence of the difference between ADR and and RevPAR is profound for the model of tourist development in Cape Verde.

The limitations to this analysis should be recognized. First, this definition of 'local benefit' is partial and limited to the data which is available. There would be merit in bringing additional criteria into the 'local benefit' calculation - for instance, the environmental impact, which is not part of the scope of this study. The second weakness of the analysis is that it focuses entirely upon the tourist establishment and does not consider spillover benefits beyond the hotel walls. The analysis therefore does not take full account of the local benefits of hotels which encourage their guests to spend time outside the hotel. Nonetheless, at present, the spillover of tourist spending outside hotels on the main tourist islands is very limited amounting to about €5 per tourist per day on Sal and Boa Vista. This reflects both the limited supply of spending opportunities outside of hotels and also the limited demand for out-of-pocket expenditure from tourists on Al packages. Having now established a critical mass of viable tourist flow onto the tourist islands in Cape Verde, there is merit in encouraging the development of out-of-resort spending by tourists and encouraging tourist flows onto less-visited islands.

\section{$<$ Insert Figure 6 around here $>$}

Several tourism strategy documents have criticized large hotels in Sal and Boa Vista as having limited linkages to the Cape Verdean economy. An alternative is advocated for smaller, non-Al establishments in other islands ${ }^{4}$. Our analysis provides empirical evidence that this seemingly intuitive policy is not entirely based on robust evidence. First, it is clear that hotel rooms in Sal and Boa Vista - particularly B\&B rooms, but also Al rooms - do generate significant local financial benefits for Cape Verde through wages for nationals, the procurement of local produce, and taxation (Table 2). Wages in Sal and Boa Vista are much higher than on the other, more populous, islands, some food is produced locally at high prices and duties are paid on imports. Finally, as room rates are healthy and occupancy rates are buoyant, taxes on turnover - such as VAT - are significant. Upmarket

\footnotetext{
4 'Specific programs will be developed to connect rural areas to the tourism sector through the value chain and to promote rural and ecological tourism' Cape Verde 2016. See also IFC Programme to mobilise investment: tourism component Grant Thornton (2007), Strategic plan for tourism development PD Consult (2008)
} 
establishments, whether B\&B or Al, generate significantly greater local impact than more standard quality accommodation.

Conversely, while rooms in smaller, less inclusive hotels in Fogo and Santo Antão tend to be more strongly-linked into the local economy in terms of the percentage of local content and supply chains, the absolute scale of local benefit is much less per hotel room per day. In Fogo and Santo Antão the average local benefit is just under €14 per room per day and in Sal and Boa Vista the average local benefit is nearly five-times higher at €67 per room per day. It should be highlighted that this is just on a relative scale based on per room per day figures.

When we look at absolute scale of local benefit, with Als dwarfing most of the others in terms of the number of rooms, the difference in local economic impact is even starker with almost all of the local benefit to Cape Verde generated by the large, Al resorts on the tourist islands.

\section{<Insert Table 2 around here $>$}

Overall, the hotels with the strongest local content are B\&B hotels in the tourist islands. These establishments have the same characteristics as the large Als (i.e. high room rates and occupancy and high staff wages and taxes) but, in addition, spend much more on food than Als and procure more of their food supplies locally. To them, F\&B is an important source of revenue (rather than simply a cost, as with an $\mathrm{Al}$ ) as their restaurants attract additional customers. Yet the B\&Bs are far smaller than the Als, and therefore in most cases have less local economic impact overall. Within Als, the more up-market and locally-managed establishments have significantly higher local content.

The findings reveal that hotels on Sal and Boa Vista are spending about $€ 15 \mathrm{~m}$ on purchase of fish each year (typically frozen Hake and Cod purchased from the high-priced Spanish fish market) and transported at huge cost to Cape Verde. Meanwhile about 3,000 artisanal fishers in Cape Verde are landing fresh, high-quality, line-caught Tuna, Wahoo and Grouper at much lower prices than the hotels are paying for imported fish and failing to find a market. Tourists are currently paying high prices for lower quality fish. The failure to link these two markets is largely due to hoteliers concerns with the hygiene standards for the locally-caught fish. In discussion with hoteliers and fishers, a certified fish handling process could overcome this concern.

The results indicate that the employment of Cape Verdeans in hotels in Cape Verde is an important local economic linkage. Although the proportion of tourism jobs filled by local nationals is currently high at $87 \%$, it should be raised and certainly must not be allowed to fall. Cape Verde has fallen into the common trap of overlooking human resource development when planning tourism (Liu and Wall 2004). The two key constraints on hotels 
recruiting more local staff are the low level of basic hospitality service skills and the poor standard of housing for hotel workers, particularly in Boa Vista.

Having succeeded in creating a significant tourist flow in a new destination with limited local infrastructure through the development of Al resorts, the emphasis should now be on maximizing the local benefit from the tourist flow. Four key recommendations are proposed:

At a sector level, local benefit can be maximised by marketing and governance initiatives to maintain and enhance the quality of the destination. Encouraging diversification of the tourist product into more $B \& B$ hotels and also onto the less-visited islands should be a priority. This process should allow space for Cape Verdeans, rather than overseas tour operators, to establish a 'brand' for Cape Verde (Santos and Campo 2014).

At an hotel level, the following recommendations can be implemented relatively quickly and easily:

- the supply of locally-caught fish would be encouraged by implementing a certified fish handling process;

- Vocational training in hospitality skills at secondary school level should take place; and

- Government should use some of the revenue generated from hotel land sales to finance upgrading tourist worker housing on the islands of Sal and Boa Vista.

\section{Conclusions}

Much academic discussion about SIDS and tourism and development impact is not based on robust evidence. Our detailed study in Cape Verde indicates that - even a very small, fragile SIDS has significant autonomy to determine its development path. Cape Verdeans successfully and unilaterally changed their entire political system and economic development policy in the early 1990s. This is demonstrated by the democratic transition in 1991 and robust governance record thereafter, Cape Verde's non-aligned status and the economic policy programme to encourage tourism Foreign Direct Investment from the 1990s.

It should be recognised that, for destinations at an early stage in their development, largescale Als may be the most effective way to achieve the rapid growth of tourism to the point that a critical mass is achieved and key infrastructure, like airports, can be justified. Als can generate rapid economic growth which can significantly reduce poverty through employment, supplier networks and taxation - which benefits residents who do not even meet a tourist. 
The intuitive appeal of smaller establishments with strong local supply linkages is valid where room rates and occupancy rates can be maintained at a high level. Given their smaller size, these establishments will have less impact on the macro-economy but more positive impact on the local economy on a per guest night basis. The lower room rates and occupancy rates, of eco-tourism resorts on the non-tourist islands constrain their ability to achieve transformative change and reduce poverty at scale. So, they should not be seen as an alternative to volume, high-end tourism - but rather a complement to it. Generating local benefits for destinations from tourism appears to be as much about achieving fullyutilised high-end tourism as it is about the choice of any particular type of package arrangement - be it Al or B\&B or Community-Based Tourism .

Our analysis indicates the importance of supporting a high-end tourist offering in Cape Verde. Many of the key benefit-streams to the destination from tourism would be eroded if Cape Verde were put under pressure to squeeze room rates. Tourist staff wages could come under pressure and tax revenues would drop. It is therefore important for the country to protect and enhance the quality of its tourism offering. We suggest this aim can be encouraged through a package of measures : better management of the sector; improving the quality of hotel supplies; and, improving the diversity of the product offering. In addition and more directly, the Government can focus their generous range of fiscal incentives for tourism investors, to incentivise investment in the specific geographic areas and market niches where they wish to see future development.

We believe that this Cape Verde case study suggests a sensible sequence to the development of tourism destinations.

First, accepting that initially there is limited tourism infrastructure and limited tourist awareness of the destination, encouraging foreign investment in large Al resorts is a pragmatic policy to encourage the rapid kick-start to the sector. Without viable tourist flows and the infrastructure that these require, there is a limit to the value of worrying about the model of tourism development. However, this initial growth phase should be relatively circumscribed because, whilst it is essential to get tourism flows up to a critical mass, it does place the sector largely in the hands of foreign interests.

Second, when significant tourist flows have become established, there is value in looking beyond just arrival numbers and tourist spend statistics to explore realistic opportunities to increase the linkages between the tourist sector and the local economy to maximize the local benefit from, and ownership of, tourism assets. Our analysis indicates that there is significant scope to encourage linkages which benefit the tourist experience, hoteliers viability and the domestic economy.

Third, a logical consequence of the activities that encourage local linkages and indigenous ownership of tourism activity, can trigger the development of the non-tourist sector. With improved communications infrastructure, stronger domestic entrepreneurialism and exposure to the tastes of overseas market players (i.e. tourists and foreign suppliers), it 
becomes much easier for SIDS to develop viable non-tourist exports to overseas markets. Rather than being an end-state, tourism can become the stepping stone to improved global competitiveness.

In terms of future research, we hope that presenting this case study of Cape Verde demonstrates the value of discussing the development performance of categories of developing countries (like SIDS) and sectors (like tourism) that are based on robust evidence, rather than assumption or anecdote.

\section{References}

CD Alvarez-Albelo and Hernandez-Martin, R (2009) Specialisation in luxury goods, productivity gaps and the rapid growth of small tourism countries Tourism Economics 15 (3) pp567-589

W Anderson (2012) Analysis of 'All-Inclusive' tourism mode in the Balearic Islands Tourismos: An international multidisciplinary journal of tourism 7 (1) pp309-323 Wineaster Anderson, (2013),"Leakages in the tourism systems: case of Zanzibar", Tourism Review, Vol. 68 Iss 1 pp. 62 - 76

Barrowclough, D. (2007). Foreign investment in tourism and small island developing states. Toruism Economics, 13(4), 615-638.

B Baker (2009) Cape Verde: Marketing good governance, Africa Spectrum Vol 44, No. 2, pp 135-147

R Brau, Lanza, A and Pigliaru, F (2003) How fast are tourism countries growing? The crosscountry evidence in FEEM (Fondazione Eni Enrico Mattei), Milan Working Paper No. 85 SJ Camilleri and Falzon, J (2013) The challenges of productivity growth in the small island states of Europe: A critical look at Malta and Cyprus Island Studies Journal 8 (1) pp131-164 SMS Canizares, JM Nunez Tabales, FJF Garcia (2014) Local residents attitudes towards the impact of tourism development in Cape Verde, Tourism \& Management Studies, 10 (1) Ciftci, H., Duzakin, E. and Onal, Y. (2007). All inclusive system and its effects on the Turkish tourism sector, Problems and Perspectives in Management, 5(3): 269-285.

RB Cizel; Cizel, B; Sarvan, F and Ozdemir, B (2011) Emergence and spread of an AllInclusivesystem in the Turkish tourism sector and strategic responses of accommodation firms International Journal of Hospitality and Tourism Administration 14 pp 305-340 A Correia; Oliveira, N and Butler, R (2008) First-time and repeat visitors to Cape Verde: the overall image Tourism Economics 14 (1) pp185-203

CountryWatch (2015) Cape Verde Country Review 2015

Croes, R. (2014). The role of tourism in poverty reduction: an empirical assessment. Tourism Economics, 20(2): 207-226.

Stephan Dercon et al (2014) Economic Transformation, internal DFID paper H Goodwin (2008) Tourism, local economic development and poverty reduction Applied Research in Economic Development 5 (3) pp 55-63

Jackman, M., Lorde, T., Lowe, S. and Alleyne, A. (2011). Evaluating tourism competitiveness of small island developing states: a revealed comparative advantage approach. Anatolia, 22(3): 350-360. 
D Lee; Hampton, M and Jeyacheya, J (2014) The political economy of precarious work in the tourism industry in small island developing states Review of International Political Economy 22 (1) pp 194-223

Liu, A. and Wall, G. (2004). Planning tourism employment: a developing country perspective. Tourism Management 27, pp.159-170.

T Lopez-Guzman; Borges, O; Hernandez-Merino, M and Cerezo, JM (2013) Tourism in Cape Verde: an analysis from the perspective of demand Tourism Economics 201319 (3) pp 675688

Master, H. \& Prideaux, B. (2000). Culture and vacation satisfaction: a study of Taiwanese tourists in Sought East Queensland. Tourism Management, 21, 445-449.

P Meyns (2002) Cape Verde: An African exception, Journal of Democracy 13 (3), pp153-165 J Mitchell (2008) Tourism development in Cape Verde: The policy challenge of coping with success A report on the tourism component of the Cape Verde Diagnostic Trade Integration Study of the Integrated Framework for trade-related technical assistance to Least Developed Countries, coordinated by the United Nations Development Programme J Mitchell and Ashley, C (2010) Tourism and Poverty Reduction: Pathways to Prosperity, EarthScan, London

Ozdemir, B., Beykan, C. and Bato, R. (2012). Satisfaction with all-inclusive tourism resorts: the effects of satisfaction with destination and destination loyalty. International Journal of Hospitality \& Tourism Administration, 13(2): 109-132.

Pratt, S. (2015). The economic impact of tourism in SIDS. Annals of Tourism Research, 52: 148-160.

Ridderstaat, J., Croes, R. and Nijkamp, P. (2014) Tourism and long-run economic growth in Aruba. International Journal of Tourism Research. 16: 472-487.

MA Riberio; Do Valle, PO; Silva, JA (2013) Residents attitudes towards tourism development in Cape Verde Islands Tourism Geographies 15 (4) pp654-679

ERM Santos and Campo, MLR (2014) Destination branding: A reflective analysis of Brand Cape Verde Place Branding and Public Diplomacy 10 (1) pp 87-102

R Scheyvens and Momsen, JH (2008) Tourism and poverty reduction: issues for Small Island States Tourism Geographies 10 (1) pp22-41

R Scheyvens and Momsen, J (2008) Tourism in Small Island States: from vulnerabilities to strengths Journal of Sustainable Tourism 16 (5) pp 491-510

Scheyvens, r. and Momsen, J. (2008) Tourism and Poverty Reduction: Issues for Small Island States, Tourism Geographies: An International Journal of Tourism Space, Place and Environment, 10:1, 22-41.

A Shakeela and Ruhanen, L and Breakly, N (2011) The role of employment in the sustainable development paradigm - the local tourism labour market in Small Island Developing States Journal of Human Resources in Hospitality \& Tourism 10 pp331-353

R Sharpley and Ussi, M (2012) Tourism and governance in Small Island Developing States (SIDS): the case of Zanzibar International Journal of Tourism Research 16 pp87-96 Travelwatch (2006). Increasing local economic benefits from the accommodation sector in the Eastern Caribbean. Accessed on 13 April 2016 http://www.thetravelfoundation.org.uk/images/media/2._Increasing_local_economic_bene fits_from_the_accommodation_sector_in_E_Caribbean_-_Full_report(1).pdf United Nations (2010) Cape Verde: An emerging nation CS Wong and Kwong WY (2004) Outbound tourists' selection criteria for choosing allinclusive package tours Tourism Management 25(5) pp 581-592 
World Bank (2013) Tourism development in Cape Verde: Is it time to abandon the AllInclusive model? World Bank Report, Washington

World Bank (2015) World Development Indicators. Accessed on 18 April 2016:

http://data.worldbank.org/sites/default/files/wdi-2015-frontmatter.pdf

World Travel and Tourism Council (2015) Cape Verde Country profile. 
Table 1: Interviews undertaken in this study

\begin{tabular}{|c|c|c|c|c|c|}
\hline \multirow[t]{2}{*}{ Island } & \multicolumn{3}{|c|}{ Accommodation } & \multirow{2}{*}{$\begin{array}{l}\text { Other private } \\
\text { sector }\end{array}$} & \multirow[t]{2}{*}{ Public sector / parastatal } \\
\hline & $\mathrm{B} \& \mathrm{~B}$ & All-Inclusive & Condo & & \\
\hline Santiago & $\begin{array}{l}1 \text { hotel } 121 \\
\text { rooms, } 4 \text { star }\end{array}$ & & & & $\begin{array}{l}\text { Ministries of: Planning \& Finance; } \\
\text { Taxation; and Rural Development; } \\
\text { Hotel school of Cape Verde; } \\
\text { World Bank }\end{array}$ \\
\hline Sal & $\begin{array}{l}2 \text { hotels, } 50 \\
\text { and } 121 \\
\text { rooms, } 3 \text { and } \\
4 \text { star }\end{array}$ & $\begin{array}{l}4 \text { large all } \\
\text { inclusive } \\
\text { (total of 1,396 } \\
\text { rooms, } 4 \text { and } \\
5 \text { star) }\end{array}$ & $\begin{array}{l}\text { Tecnicil Villa } \\
\text { Verde }(1,200 \\
\text { units })\end{array}$ & $\begin{array}{l}\text { Large F\&B and } \\
\text { goods supplier to } \\
\text { hotel sector; } \\
\text { Hotel construction } \\
\text { company; tour } \\
\text { operator }\end{array}$ & $\begin{array}{l}\text { ASA (Airport Authority); } \\
\text { Agency for business development } \\
\text { \& innovation; } \\
\text { Sal Rei Local authority and Port } \\
\text { Authority }\end{array}$ \\
\hline $\begin{array}{l}\text { Bua } \\
\text { Vista }\end{array}$ & $\begin{array}{l}1 \text { hotel } 28 \\
\text { rooms } 3 \text { star }\end{array}$ & & & & $\begin{array}{l}\text { SDTIBM (Boa Vista \& Maio } \\
\text { Island Tourism Corporation) }\end{array}$ \\
\hline $\begin{array}{l}\text { Santa } \\
\text { Antao }\end{array}$ & $\begin{array}{l}1 \text { hotel } 23 \\
\text { rooms, } 2 \text { star } \\
\text { and } 1 \text { guest- } \\
\text { house } 4 \\
\text { rooms }\end{array}$ & & & & \\
\hline Fogo & $\begin{array}{l}1 \text { hotel } 39 \\
\text { rooms } 4 \text { star, } \\
\text { and } 1 \text { guest- } \\
\text { house } 10 \\
\text { rooms }\end{array}$ & & & $\begin{array}{l}1 \text { tour operator; } 1 \\
\text { winery. }\end{array}$ & \\
\hline
\end{tabular}


Table 2: Share of Local Content of Selected Hotels

\begin{tabular}{|c|c|c|c|c|c|c|}
\hline \multirow[b]{2}{*}{ Island } & \multirow[b]{2}{*}{ Type of Accommodation } & \multirow{2}{*}{$\begin{array}{l}\text { Total local } \\
\text { content per } \\
\text { room per } \\
\text { day }(€)\end{array}$} & \multicolumn{4}{|c|}{ Share of Local Content (\%) } \\
\hline & & & $\begin{array}{c}\text { Non- } \\
\text { Mgmt } \\
\text { Staff }\end{array}$ & Food & Beverages & Tax \\
\hline \multirow{2}{*}{ Sal } & Upmarket, Large Al & 53 & 32 & 1 & 4 & 63 \\
\hline & Small B\&B Hotel & 102 & 29 & 34 & 2 & 36 \\
\hline \multirow{2}{*}{$\begin{array}{l}\text { Boa } \\
\text { Vista }\end{array}$} & Large Al & 28 & 20 & 0 & 6 & 74 \\
\hline & Medium Al & 64 & 25 & 25 & 13 & 37 \\
\hline \multirow{2}{*}{ Fogo } & Small Hotel & 14 & 27 & 14 & 5 & 54 \\
\hline & Upmarket B\&B & 27 & 36 & 13 & 4 & 47 \\
\hline \multirow{2}{*}{$\begin{array}{l}\text { Santo } \\
\text { Antão }\end{array}$} & Medium Hotel & 9 & 28 & 17 & 5 & 50 \\
\hline & Small Hotel & 10 & 21 & 5 & 31 & 43 \\
\hline
\end{tabular}

Source: World Bank 2013, based upon the authors primary research 
Figure 1: The 12 most tourism-dependent countries in 2013

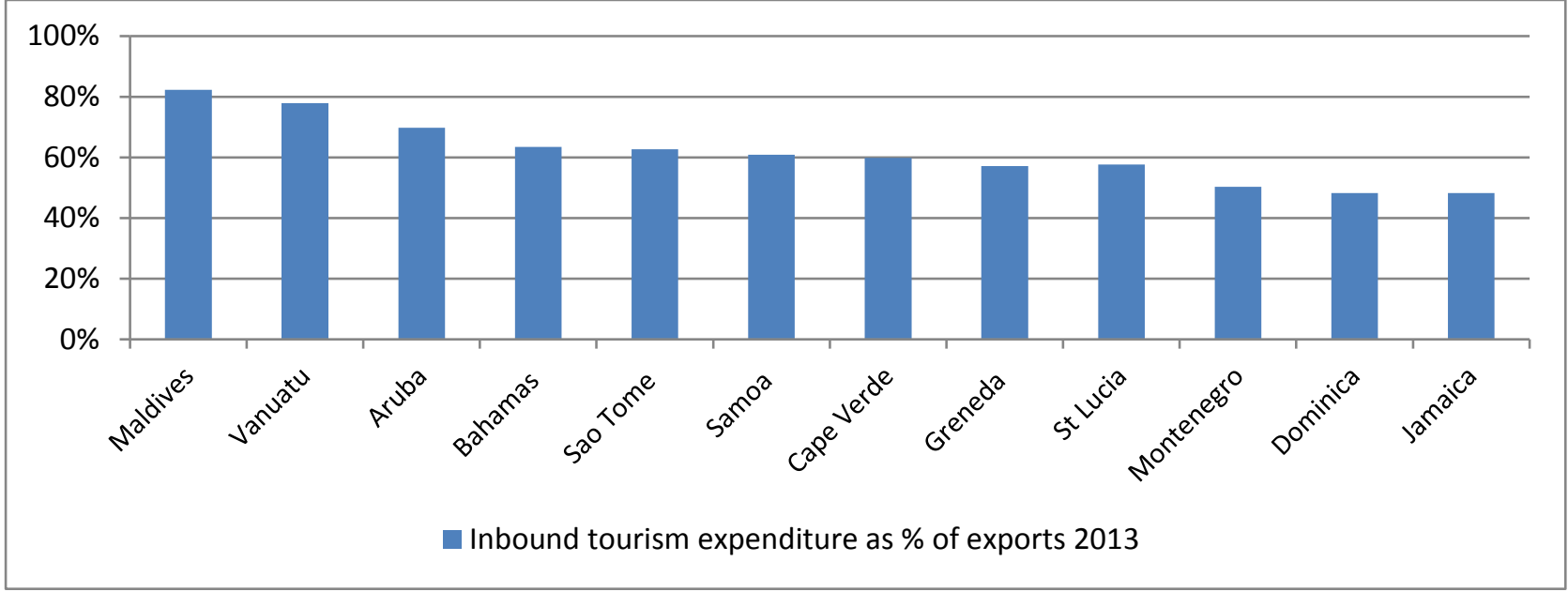

Source: World Bank 2015 
Figure 2: Location of Cape Verde and the islands of the Archipelago

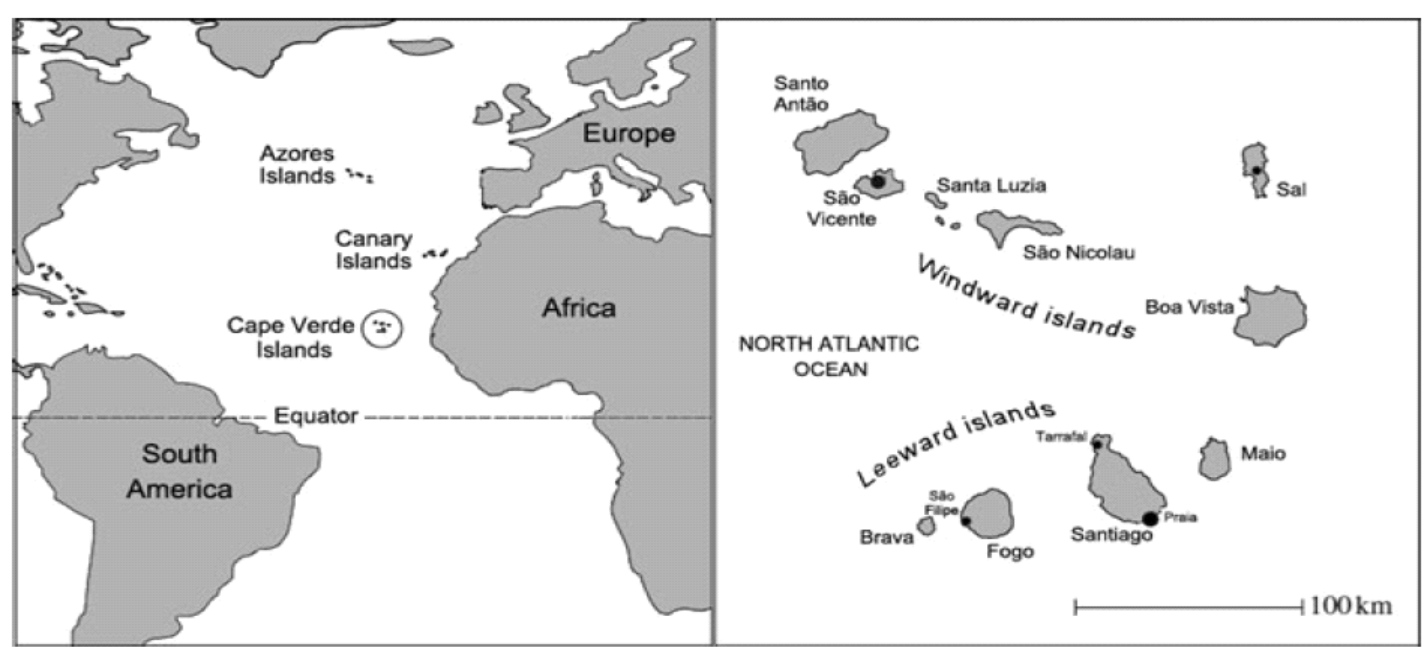


Figure 3: International Tourist Arrivals, 1999-2011

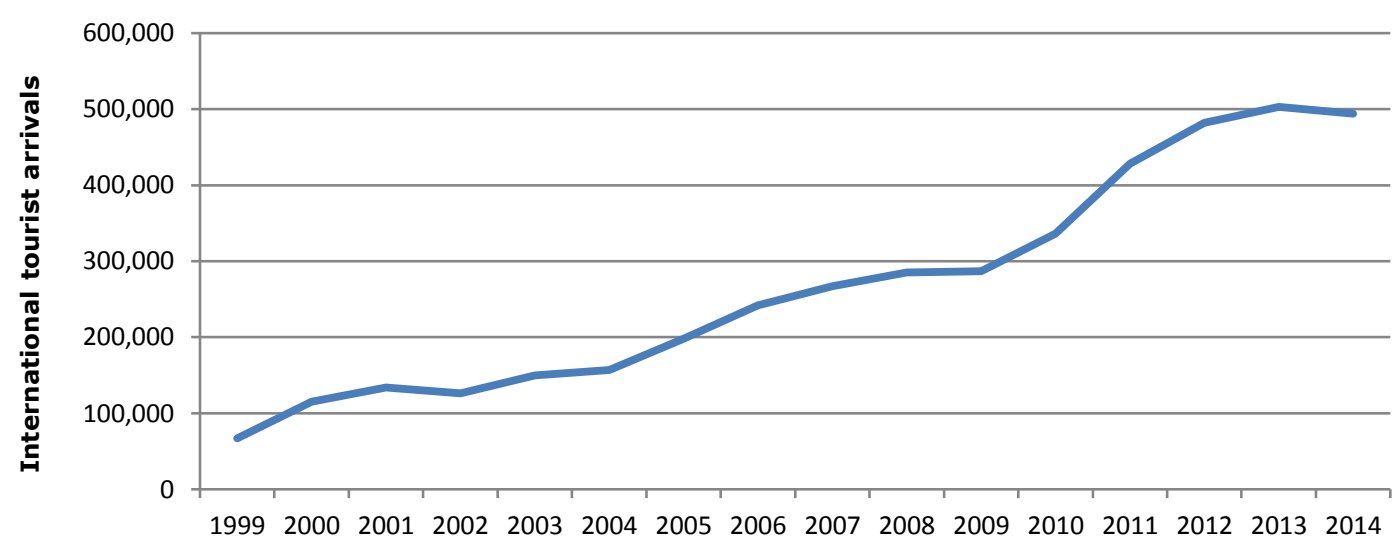

Source: World Bank WDI (2015) 
Figure 4: Key economic activities as a share of GDP, 1998 to 2011

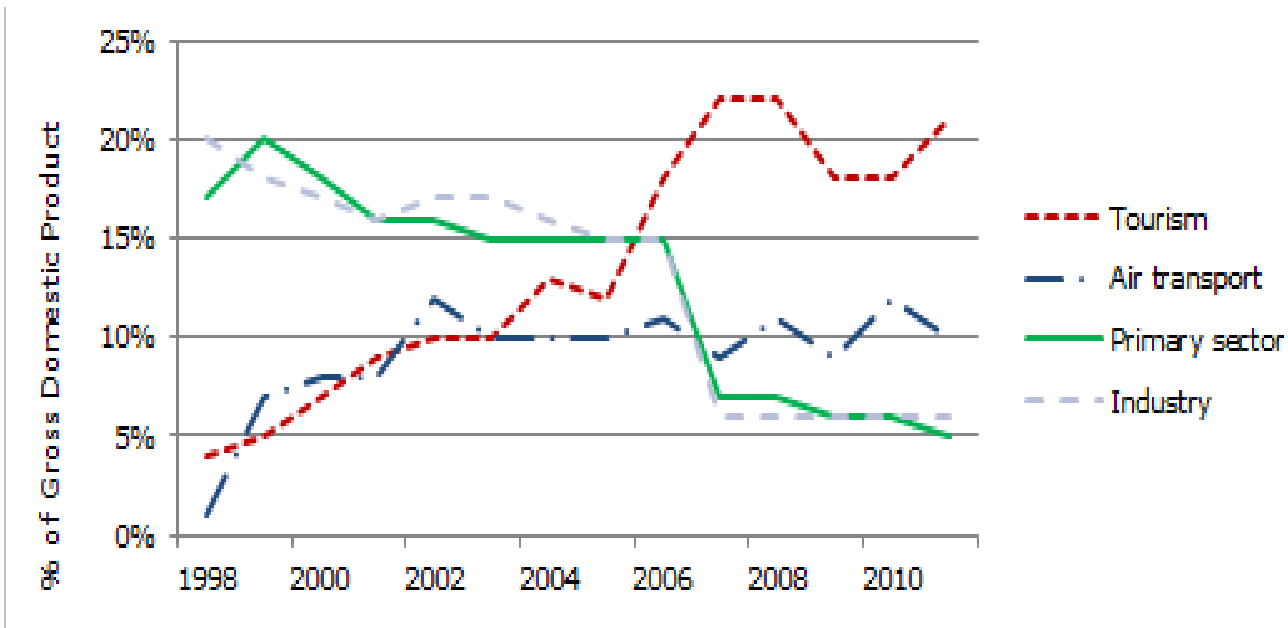

Source: World Bank 2013 
Figure 5: Changes in poverty incidence from 2000 to 2010

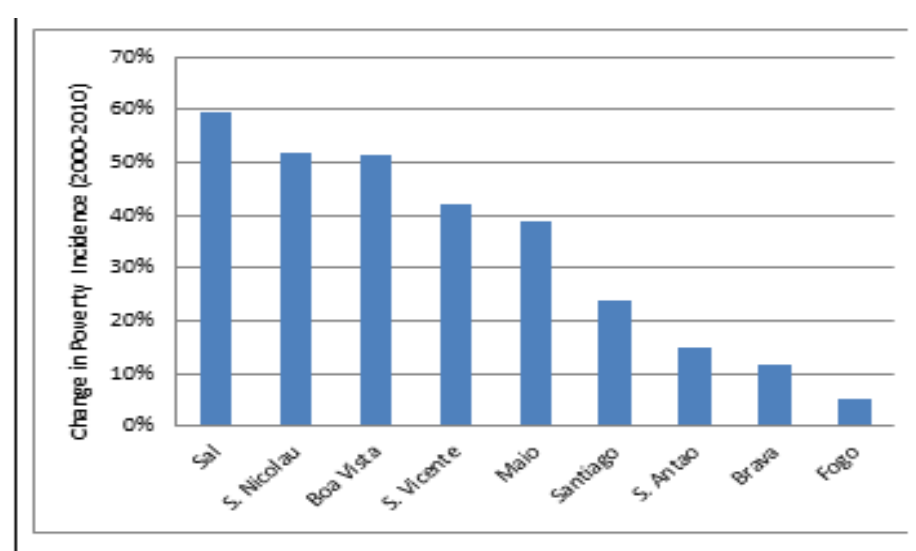

\begin{tabular}{lcc|}
\multicolumn{3}{c}{ Poverty } \\
\hline \multicolumn{1}{c}{ Island } & $\mathbf{2 0 0 0}$ & $\mathbf{2 0 1 0}$ \\
\hline Sal & 25 & 10 \\
S. Nicolau & 44 & 21 \\
Boa Vista & 23 & 11 \\
S. Vicente & 29 & 17 \\
Maio & 34 & 21 \\
Santiago & 37 & 28 \\
S. Antão & 48 & 41 \\
Brava & 43 & 38 \\
Fogo & 42 & 40 \\
\hline Total & $\mathbf{3 7}$ & $\mathbf{2 7}$ \\
\hline \multicolumn{2}{l}{}
\end{tabular}

Source: World Bank 2013 
Figure 6: Hotel performance and local content (bubble areas represents local benefit per room per day in $€$ )

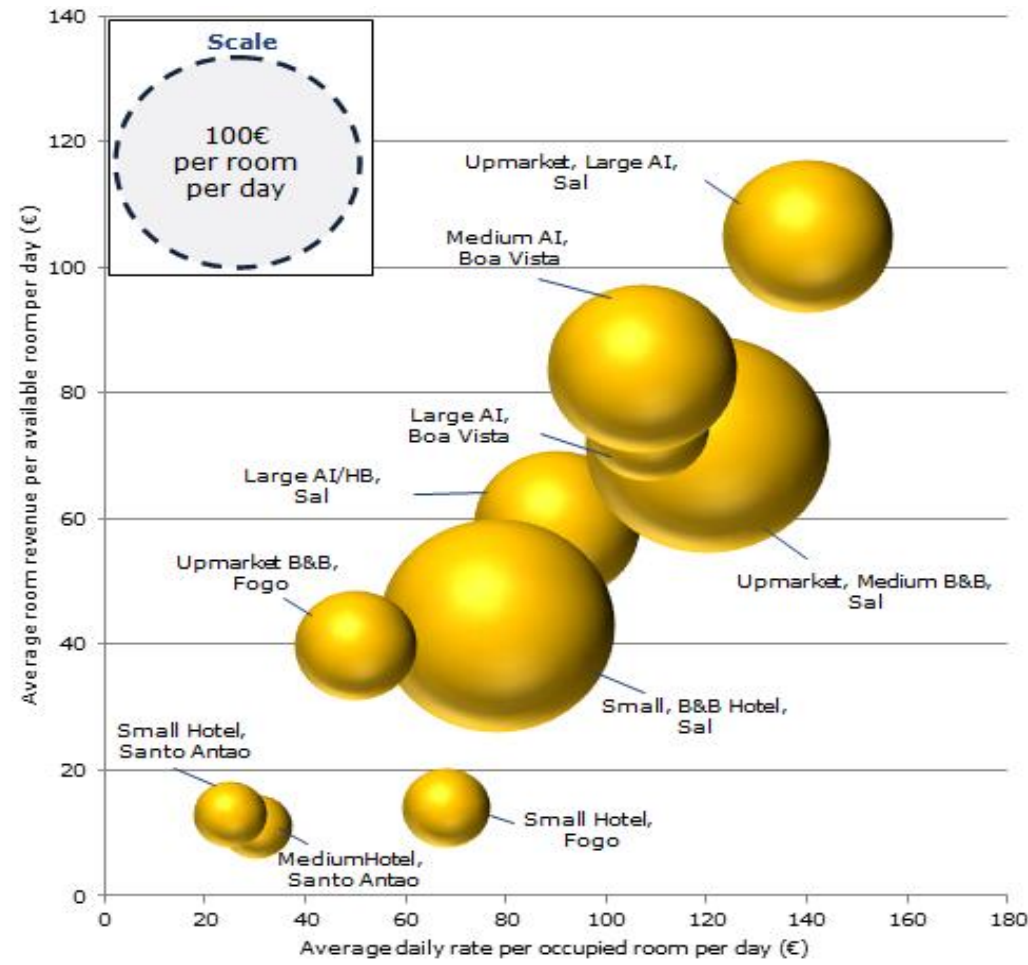

